\title{
Effects of the psychological characteristics of CEOS at the levels of business internationalization: the case of the born global in Latin America ${ }^{1}$
}

\section{Fecha de recepción: 12 de abril de 2019

Cómo citar este artículo / To reference this article / Comment citer cet article / Para citar este artigo:

García-Cediel, G. (2021). Effects of the psychological characteristics of CEOS at the levels of business internationalization: the case of the born global in Latin America. Revista Escuela de Administración de Negocios, (90), 123-138. DOI: https://doi. org/10.21158/01208160.n90.2021.2849

\begin{abstract}
The aim of this document is to analyze not only the relationship among orientation towards innovation, proactiveness, and risk tolerance, chosen by the literature as three of the most important psychological characteristics of CEOs, but also the export intensity in a special type of firms: the Born Global, characterized by being small firms that, before completing their first three years up and running, have already started international operations with more than $25 \%$ of their sales directed to international markets. The theoretical framework of the paper uses the Upper Echelons approach, which considers that the demographic and psychological characteristics of the management team end up being determinant in the results of the companies. A Binary Logistic Regression based on data from the Global Entrepreneurship Monitor in twelve Latin American countries in 2016 was used as the statistical analysis methodology. As a result, it is found that the orientation towards innovation, studied from product and process innovation, is determinant to achieve successful internationalization processes. In contrast, proactiveness and risk tolerance were found to be non-determinant. This implies that companies should take measures to decisively promote innovation and intra-entrepreneurship mechanisms within themselves, and thus facilitate their integration into international markets.
\end{abstract}

Keywords: Born Global firms; business internationalization; orientation towards innovation; innovation mechanisms; export intensity; international markets.

\footnotetext{
1 This article is derived from the thesis entitled «Export intensity in Born Global Firms in emerging countries: empirical evidence from the perspective of the Upper Echelons approach» submitted to the University of Valencia for the degree of Doctor in Business Administration, currently under development.

2 Economist - Industrial University of Santander. Specialist in Finance with an emphasis in Investment Banking - Externado de Colombia University. Master in Economics - Pontificia Universidad Javeriana. Candidate for the Doctor of Business Administration degree - University of Valencia. Member of the Labor Market Research Group. ORCID: https://orcid.org/0000-0002-3286-6832
} 


\section{$\longrightarrow \quad$ Efectos de las características psicológicas del CEOS en los niveles de internacionalización empresarial: el caso de las Born Global en América Latina}

\section{Resumen}

Este documento tiene como objetivo analizar la relación entre la orientación a la innovación, la proactividad y la tolerancia al riesgo, escogidas por la literatura como tres de las características psicológicas más importantes de los CEO, y la intensidad exportadora en un tipo especial de firmas como son las Born Global, las cuales se caracterizan por ser firmas pequeñas que, antes de los tres años, ya han iniciado operaciones internacionales y donde más del $25 \%$ de sus ventas se dirigen a los mercados internacionales. Como marco teórico del documento se utiliza el enfoque Upper Echelons el cual considera que las características demográficas y psicológicas del equipo directivo terminan siendo determinantes en los resultados de las compañías. Como metodología de análisis estadístico se utilizó una Regresión Logística Binaria basada en los datos del Global Entrepreneurship Monitor utilizando datos de doce países de Latinoamérica en el año 2016. Como resultado se encuentra que la orientación a la innovación, estudiada desde la innovación de productos y de procesos, es determinante para lograr procesos exitosos de internacionalización. Por el contrario, la proactividad y la tolerancia al riesgo resultaron ser no determinantes. Ello implica que las compañías deben tomar medidas para promover decididamente los mecanismos de innovación e intra emprendimiento al interior de ellas y con ello facilitaran su inserción en los mercados internacionales.

Palabras clave: occupational safety and health; experience frameworks; regulatory framework; strategic framework; moral framework; organizational communication.

\section{$\rightarrow \quad$ Efeitos das características psicológicas dos CEOs nos níveis de internacionalização empresarial: o caso das Born Global na América Latina}

\section{Resumo}

Este documento tem como objetivo analisar a relação entre a orientação à inovação, a proatividade e a tolerância ao risco, escolhidas pela literatura como três das características psicológicas mais importantes dos CEOs, e a intensidade exportadora em um tipo especial de firmas como a Born Global, que se caracterizam por serem pequenas empresas que, antes de três anos, já iniciaram operações internacionais e mais de $25 \%$ de suas vendas são direcionadas ao mercado internacional. Como referencial teórico do documento, utilizou-se a abordagem Upper Echelons, que considera que as características demográficas e psicológicas da equipe de gestão acabam por ser determinantes nos resultados das empresas. Como metodologia de análise estatística, foi utilizada a Regressão Logística Binária com base nos dados do Global Entrepreneurship Monitor, utilizando dados de doze países da América Latina em 2016. Como resultado, notou-se que a orientação para a inovação, estudada a partir da inovação de produtos e processos, é decisiva para alcançar processos bem-sucedidos de internacionalização. Ao contrário, a proatividade e a tolerância ao risco revelaram-se não determinantes. Isso implica que as empresas devem tomar medidas para promover de forma decisiva os mecanismos de inovação e intraempreendedorismo dentro delas e, assim, facilitar a sua inserção nos mercados internacionais.

Palavras-chave: Empresas Born Global; internacionalização empresarial; orientação à inovação; mecanismos de inovação; intensidade de exportação; mercados internacionais. 


\section{Caractéristiques psychologiques des dirigeants d'entreprise (PDG) et effets sur le taux d'internationalisation des organisations: le cas des sociétés de type Born Global en Amérique latine}

\section{Résumé}

Ce document vise à analyser la relation entre l'innovation, la proactivité et la tolérance au risque - trois des caractéristiques psychologiques les plus importantes des PDG - avec la propension à l'exportation des entreprises de type Born Global - entreprises ayant déjà réalisées des exportations ou opérations internationales pour plus de $25 \%$ deleurs ventes - avant leur troisième année d'existence. Le cadre théorique du document s'inspire de l'approche de type Dernier Echelon qui analyse les caractéristiques psychologiques de l'équipe de direction considérée comme déterminantes pour les résultats des entreprises. Une méthodologie d'analyse statistique de régression logistique binaire a été utilisée sur la base d'informations du Global Entrepreneurship Monitor consolidant les données de douze pays d'Amérique latine en 2016. L'étude montre que l'innovation des produits et processus est décisive dans la réussite des démarches d'internationalisation. La proactivité et la tolérance au risque ne se sont en revanche pas avérées déterminantes dans le processus. Les entreprises doivent donc prendre des mesures fortes pour promouvoir l'innovation et les mécanismes intra-entrepreneuriaux permettant leur insertion sur les marchés internationaux.

Mots-clés: entreprises Born Global; internationalisation des ventes; orientation à l'innovation; mécanismes d'innovation; intensité des exportations; marchés internationaux. 


\section{Introduction}

S nce the late eighties, the academic literature showed great interest in studying accelerated internationalization companies, a name that has been given to those companies that start foreign trade operations from their inception or shortly after, and therefore, do not follow the traditional pattern proposed by the Uppsala model (Johansson \& Vahlne, 1977; 1990), which establishes that internationalizing companies requires a gradual and slow process that includes different stages to dominate the domestic market from the very beginning and then, with the experience gained, overcome the obstacles and stages that are involved in the internationalization process - export, establishment of sales subsidiaries, establishment of production subsidiaries-.

These types of companies have been called in different ways: Born International Small Medium Enterprises (Kundu \& Katz, 2003); Committed Internationalists (Bonaccorsi, 1992); Micro internationals (Dimitratos, Johnson, Slow, \& Young, 2003); High Early Internationalizing Firms (Rialp, Rialp, \& Knight, 2005); and Global Start-Ups (Oviatt \& McDougall, 1994); but the definitions of Born Global that have been more broadly accepted in the literature are: «small firms from technological sectors that operate in international markets from the first days of their establishment» (Knight \& Cavusgil, 1996, p.11), and International New Ventures: «Organizations that, from inception, seek to obtain competitive advantages from the use of resources of international origin and the sale of their products in several countries $>$ (Oviatt \& McDougall, 1994, p.49). In this document we will welcome the concept of Born Global. This concept has already been operationalized and defines those companies that reach foreign trade processes before three years of operation and that derive at least $25 \%$ of their income from sales abroad (Kuivalainen, Sundqvist, \& Servais, 2007; Jantunen et al., 2008; Milanov \& Fernhaber, 2009)
Several authors agree that the reasons that have promoted the emergence of these types of companies include: a) globalization understood as the decrease in transport costs, communication, and tariff rates (Madsen \& Servais, 1997; McAuley, 1999); b) the development of ICTs that have facilitated the creation of business networks and alliances between entrepreneurs at the global level (Bell, 1995; Corviello \& Munro, 1995); and c) the best skills of entrepreneurs in terms of their training and experience, and their ability to take advantage of new technologies to face the challenges that an internationalization process brings, considering that they are small and very young companies, for what it is the strategies of the managers what allows to overcome these challenges (Knight, 2000; Moen, 2002).

However, we consider that further research on this last aspect is required; that is, on the way the characteristics of human capital affect internationalization operations (Leonidou, Katsikeas \& Piercy, 1998; Miesenbock, 1988; O'Cass \& Julian, 2003; Reid, 1983). Occasionally, some authors point out that there is a lack of studies on the psychological characteristics of the management team and its effect on the performance of the company. As Acedo and Jones (2007, p.237) argue: «Few studies in the emerging field of International Entrepreneurship have focused on the individual, much less analyzed the individual's psychological traits $\gg$.

In this way, this document aims at suggesting evidence to cover this research gap by exploring the relationship between the psychological characteristics of the CEOs in Born Global (BG) firms and the levels of internationalization, measured in this case by the concept of export intensity, referring to the percentage of profits generated by sales abroad on total sales. As a theoretical framework, we used the Upper 
Echelons approach, which establishes a direct relationship between the demographic and psychological characteristics of the management team and the strategies that trace them, which in the fullness of time end up influencing the performance of the company.

In this fashion, the article has a practical motivation because it seeks to establish how a certain psychological profile ends up influencing the performance of the company. Therefore, it could be useful to establish suitable profiles for those companies that are looking for managers for their internationalization areas.

The document also makes an important contribution to literature in several points: first, it analyzes this type of relationship for emerging countries, especially for Latin America, as the absence of this type of analysis is evident. As argued by Rialp et al. (2005):
It has been found that these types of firms exist in places as diverse as Australia, the United States, Canada, Switzerland, Ireland, New Zealand, the United Kingdom, Germany, France, Spain, Israel, and the Nordic countries (Denmark, Sweden, Norway, and Finland). However, future research should cover other areas, particularly in less developed countries (p.156).

Then, it provides empirical evidence to help consolidate the theory about this type of firms in the face of the lack of development of a solid theoretical body around this type of companies (Jones, Coviello, \& Tang, 2011).

The article is developed as follows: the first section presents the context, the research gap, and its objectives and contributions to the theory. The second section addresses the theoretical framework and raises the hypothesis. The third section shows the methodology to be used, and finally, we present the analysis of results and conclusions.

\section{Theoretical foundation}

$\mathrm{T}$ The theoretical framework considered appropriate for the purposes of this document is the Upper Echelons approach (EUE by its abbreviation in Spanish) or Theory of the Upper Scales, developed by Hambrick and Mason (1984), who argued that there are psychological and demographic characteristics that determine the decisions of the management team and that end up affecting the performance of the company.

In the words of these authors: «if the strategic choices have a high behavioral component, then to a certain extent, the elections reflect the idiosyncrasies of the decision makers» (Hambrick \& Mason, 1984, p.195). One of these decisions is how the internationalization strategy is going to be carried out. That said, the theoretical framework is considered ideal to analyze the relationship between the psychological characteristics of the management team and the levels of internationalization in BG firms.

Hambrick and Mason (1984) explain the process that determines this relationship: a) the decisions adopted, and therefore the results of the company, are determined by the mental structure of the management team; b) the mental structure of the team is shaped by psychological characteristics that in turn are influenced by demographic characteristics; c) In conclusion, the results of the company depend on the psychological characteristics of the management team. Graphically, the model proposed by Hambrick and Mason (1984) is as follows: 
Figure 1. Model of the Superior Scales theory

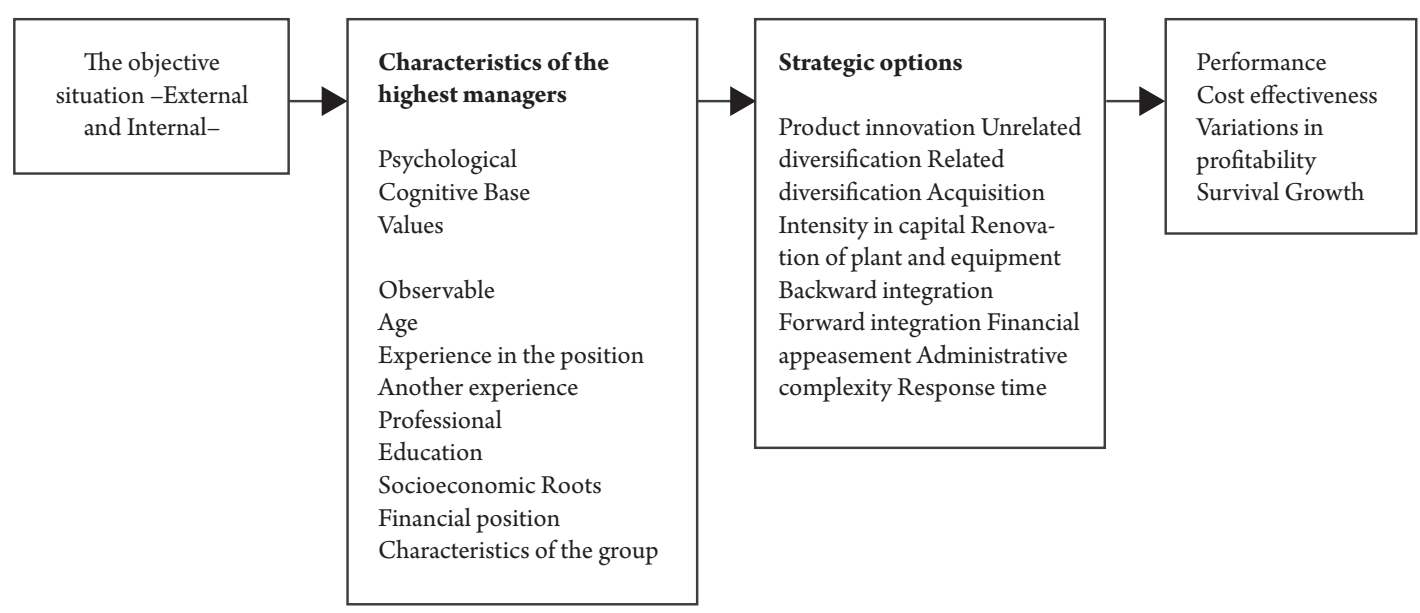

Source. Hambrick and Mason, 1984.

Within these psychological characteristics, we will focus on three of the most important, recognized by the literature: risk tolerance, proactivity, and orientation to innovation (Miller, 1983).

\subsection{Risk tolerance}

One of the psychological characteristics that is necessary for an entrepreneur, since a person who shows this ability will always assume more risks than a person who does not. Creating and taking over the management of a company is a project that involves high uncertainty. Thus, individuals who are less risk-adverse are more likely to be entrepreneurs (Caliendo, Fossen, \& Kritikos, 2009). This risk tolerance is greater when the company is not only managed but also directed towards internationalization (Matlay, Andersson, \& Evangelista, 2006; Trabold, 2002).

Different literature argues that the processes of internationalization involve a series of risks that arise from factors such as the lack of information about the new destination, geographical distance, the levels of competition of the new market, language and cultural barriers, exchange risk, and others (Leiblein \& Reuer, 2004; Liesch, Welch, \& Buckely, 2001; Ruzzier, Antoncic, Hisrich, \& Konecnic, 2007); hence, the companies that trace strategies to manage risk will be able to overcome these factors. Understanding from the fact of comprehending and matching the tastes of foreign customers, and even offering a keen price according to the context (Ahmed, Julián, Baalbaki, \& Hadidian, 2004), means that the management team must have the capacity to process more information when entering an international market, as the results will be better (Roth, 1995; Sanders \& Carpenter, 1998; Tihanyi \& Thomas, 2005). This leads us to raise the following hypothesis:

\section{Hypothesis one: For Born Global firms in emerging countries, the greater the tolerance to risk, the greater the export intensity.}

\subsection{Orientation to innovation}

Innovation is defined as «the implementation of a product - good or service-, process, method of marketing, or new or significantly improved organizational method, in business practices, a work organization, or external relations $\gg$ (OECD, 2005, p. 16). In this vein, an innovation-oriented management team will always seek the way to «change the pattern of production by exploiting an invention or, more generally, a technological possibility for producing a new commodity, or producing something old in a new way, by opening a new point of sale» (Knight \& Cavusgil, 2004, p. 126). 
This implies establishing mechanisms to implement strategies where all employees can contribute their ideas to improve production processes (Miller \& Friesen, 1983); considering that the innovation levels in emerging countries are low compared to innovation levels in industrialized countries. A BG firm that works decisively in a culture of innovation will have greater advantages over other companies in the internationalization process, which allows us to raise the following hypothesis:

Hypothesis two: For Born Global firms in emerging countries, the greater the orientation towards innovation, the greater the export intensity.

\subsection{Proactivity}

Proactivity is defined as the permanent search for $\ll$ new opportunities that may or may not be related to the current line of operations, the introduction of new products and brands ahead of competition, the strategic elimination of operations that are in the mature or declining stages of the life cycle» (Venkatraman, 1989, p. 949) and is an essential characteristic for the management team that wants to take advantage of the opportunities offered on the market. Having such behavior can allow for the effective use of new market niches and the anticipation of movements of the competition in the future. The opposite behavior is known as reactivity, and is defined as acting in response to the movements of the competition. In terms of activities, proactivity includes strategies such as attending trade fairs or being informed of new market trends (Zhou, Barnes, \& Lu, 2010).

Such information is scarce in developing countries, given the low institutional advancement and the fact that it is more difficult to attend business fairs because of their high costs, which are also determined by the exchange differentials; so those BG firms that allocate resources or subsidize from government programs to do so, will gain higher levels of internationalization. This allows us to raise the following hypothesis:

Hypothesis three: For Born Global firms in emerging countries, the greater the proactivity, the greater the export intensity.

\section{Methodology}

$\mathrm{T}$ his section presents the source of information, the variables, and the analysis technique that will be used.

\subsection{Information sources regarding the source of information}

This article uses the database produced by the Global Entrepreneurship Monitor (GEM) project. This project was born in 1999 at Babson College (EU) and London Business School (UK), and aims at «analyzing, exploring, and evaluating the role that entrepreneurship plays in the economic growth of nations by means of the creation of a harmonized and common data set between countries» (GEM, 2015, p. 16). Since its creation, groups of universities around the world have been joining, and by 2017, more than 70 countries were participating, which made of the GEM project the largest network of global research on entrepreneurship.

In addition to coverage, the GEM uses the same methodology in all the countries, making its results comparable to one another, and when adding more than 17 uninterrupted years of work, it makes it possible to do longitudinal studies. This methodology constitutes the application of the adult population survey (APS) to at least 2,000 people, where the demographic, psychological, and motivational variables for entrepreneurs and non- 
entrepreneurs are analyzed. It also investigates the characteristics of new companies and established companies in variables such as innovation and internationalization, among other factors. The other component of the GEM methodology is an interview with 36 experts in each country, also called National Expert Survey (NES), whose goal is to analyze their perception on nine factors of the entrepreneurial ecosystem. For this document, we will use the GEM database for Latin America in 2016. To test our hypothesis, we will use the GEM database for Latin America. Table 1 shows the countries and the number of individuals interviewed:

Table 1. Countries and number of sample surveys

\begin{tabular}{|c|c|}
\hline Country & Number of surveys \\
\hline Perú & 2061 \\
\hline México & 5043 \\
\hline Belice & 2297 \\
\hline Argentina & 1961 \\
\hline Chile & 9169 \\
\hline Colombia & 2061 \\
\hline Guatemala & 2216 \\
\hline El Salvador & 2091 \\
\hline Uruguay & 1987 \\
\hline Panamá & 1989 \\
\hline Puerto rico & 1990 \\
\hline Brasil & 1989 \\
\hline Total & 34854 \\
\hline
\end{tabular}

Source. Prepared by the author based on GEM, 2016.

\subsection{Variables}

As per the variables, the dependent variable is the level of internationalization using the Export Intensity as the measure, which is represented as the percentage of profits for sales abroad on total sales. This variable has already been used by different authors (Cavusgil, 1984; Dimitratos, Lioukas, \& Carter, 2004; Moini, 1997; Preece, Miles, \& Baetz, 1998; Robertson \& Chetty, 2000; Zhara \& Garvis, 2000). In GEM, this is a binary variable that will take the value of 1 when the percentage of profits generated by sales abroad is higher than $25 \%$, and 0 otherwise, and is taken from the companies in the databases with a reported existence of more than 42 months, so they fit the concept of BG.

Taking into account the literature reviewed, this study stated the proactivity, orientation to innovation, and risk aversion as independent variables. In order to measure proactivity, we used the Opport variable from the GEM database, which explores the perception of opportunities perceived by the entrepreneur with the question: In the next six months, will there be good business opportunities in the area where you live? It is a dummy variable that takes the value of 1 when the answer is positive, and 0 otherwise.

To measure risk aversion, we used the FRFAILOP variable from the database, which investigates the entrepreneur's fear of failing in a business. It is a dummy variable that takes the value of 0 if positive, and 1 otherwise.

Regarding the orientation to innovation, the GEM allowed us to investigate two aspects of innovation: process innovation and product innovation. The first one can be measured through the variable TEACUST, which investigates the perception of 
consumers regarding the novelty of their product with the question: will all, some, or none of your potential customers consider this new product or service? Being a categorical variable, we will convert it into a dummy that takes the value of 1 when the answer is all or some, and 0 when the answer is none.

The process of innovation can be measured in the GEM through the variable TEATECH, which inquiries about the antiquity of the production technologies that entrepreneurs use with the question: regarding the production technologies that are being used, have they been available for less than a year, between one and five years, or over five years being a categorical variable? For our analysis, we will convert them into a dummy variable that takes the value of 1 when responding less than a year, and 0 when responding between one and five years, or over five years. Table 2 shows the variables, the statements and answers in the GEM, and some works that have used these variables in the same sense.

Table 2. Variable list

\begin{tabular}{|c|c|c|c|c|}
\hline Variables & Construct & Questions in GEM & Answer & Reference works \\
\hline $\begin{array}{l}\text { Dependent } \\
\text { variable }\end{array}$ & Export intensity & $\begin{array}{l}\text { Does more than } 25 \% \text { of your } \\
\text { income come from overseas } \\
\text { sales? }\end{array}$ & $\begin{array}{l}\mathrm{Yes}=1 \\
\mathrm{No}=0\end{array}$ & $\begin{array}{l}\text { Bonaccorsi (1992); Capar \& } \\
\text { Kotabe (2003); Fernandez \& } \\
\text { Nieto (2006); Geringer, Tallman } \\
\text { \& Olsen, (2000); Tallman \& Li } \\
\text { (1996); Wakelin (1998) }\end{array}$ \\
\hline \multirow{4}{*}{$\begin{array}{l}\text { Independent } \\
\text { variables }\end{array}$} & Risk Tolerance & $\begin{array}{l}\text { Does the fear of failure prevent } \\
\text { you from starting a new } \\
\text { business? }\end{array}$ & $\begin{array}{l}\mathrm{Yes}=0 \\
\mathrm{No}=1\end{array}$ & Arenius \& Minniti, (2005) \\
\hline & Proactivity & $\begin{array}{l}\text { Do you think that in the next } \\
\text { six months there will be good } \\
\text { opportunities to start a business } \\
\text { in the area near where you live? }\end{array}$ & $\begin{array}{l}\mathrm{Yes}=1 \\
\mathrm{No}=0\end{array}$ & Arenius \& Minniti, (2005) \\
\hline & $\begin{array}{l}\text { Product } \\
\text { innovation }\end{array}$ & $\begin{array}{l}\text { Will all, some, or none of your } \\
\text { potential customers consider } \\
\text { this product or service new? }\end{array}$ & $\begin{array}{l}\text { All, some }=1 \\
\text { None }=0\end{array}$ & Arenius \& Minniti, (2005) \\
\hline & Process innovation & $\begin{array}{l}\text { Have the production } \\
\text { technologies that are being } \\
\text { used been available for less than } \\
\text { a year, between one and five } \\
\text { years, or over five years being a } \\
\text { categorical variable? }\end{array}$ & $\begin{array}{l}\text { Less than one } \\
\text { year }=1 \\
\text { Between one and } \\
\text { five years and } \\
\text { over five years } \\
=0\end{array}$ & Arenius \& Minniti, (2005) \\
\hline
\end{tabular}

Source. Prepared by the author based on GEM, 2016.

\subsection{Analysis method}

In order to check the hypothesis, we chose the binary logistic regression model, defined as a statistical method of multivariate analysis that is applied when the independent variable is binary or dichotomous, and obtains the value of 1 when the presence of an attribute is positive, and 0 when it is not (Alderete, 2006). In our case, it allows forecasting the probability that the percentage of income from sales abroad is greater than $25 \%$, or in other words, that it is a BG signature according to the psychological characteristics of the CEO. In this method, the data is presented according to the following expression: 


$$
\begin{aligned}
& \qquad \ln \left(\frac{p}{1-p}\right)=\beta_{0}+\beta_{1} X_{1}+\cdots+\beta_{k} X_{k}+u=X \beta+u \\
& \text { If we call } \mu=\beta_{0}+\beta_{1} X_{1}+\cdots+\beta_{k} X_{k} \text {, then } \ln \left(\frac{p}{1-p}\right)=Z+u
\end{aligned}
$$

Where $\mathrm{p}$ is the probability that the event will occur —in this case, the profits from sales abroad will be higher than $25 \%$ -

In this way, operating you have to:

$$
\begin{gathered}
\ln \left(\frac{p}{1-p}\right)=Z \\
p\left(\frac{e^{z}}{1-e^{z}}\right)
\end{gathered}
$$

According to this, the difference in the probability of an event occurring with respect to this event not happening is linear, but in a logarithmic scale. In conclusion, we want to know the probability of a firm being BG depending on the psychological characteristics of the CEO. As assumptions, the model must have linearity and independence in the errors, and cannot present multicollinearity — strong correlation between the explanatory variables of the model-.

\section{Results}

In order to check the consistency of the model, the assumptions of the model in the first place, the noncollinearity between the variables, and the independence of the errors will be tested. Table 3 shows the Durbin Watson statistic, which indicates that the errors are independent. Table 4 shows the inflation factor of variance, which indicates the non-collinearity between the independent variables.

Table 3. Statistical DW

\begin{tabular}{|c|c|c|c|c|c|}
\hline Model & $\mathbf{R}$ & R-square & $\begin{array}{c}\text { Adjusted } \\
\text { R-square }\end{array}$ & $\begin{array}{c}\text { Standard error of } \\
\text { the estimate }\end{array}$ & Durbin-Watson \\
\hline 1 &, $162^{\mathrm{a}}$ &, 026 &, 026 &, 340 & 1,649 \\
\hline
\end{tabular}

Source. Prepared by the author based on GEM, 2016 - output SPSS V23. 
Table 4. Variance inflation factor

\begin{tabular}{|c|l|r|c|}
\hline \multicolumn{2}{|c|}{ Model } & \multicolumn{2}{c|}{ Collinearity statistics } \\
\cline { 3 - 4 } \multicolumn{2}{|c|}{} & Tolerance & \multicolumn{1}{c|}{ VIF } \\
\hline \multirow{3}{*}{1} & FRFAIL adapted to make it fit for national level aggregation. &, 985 & 1,015 \\
\cline { 2 - 4 } & OPPORT adapted to make it fit for national level aggregation. &, 985 & 1,016 \\
\cline { 2 - 4 } & TEA: Were the technologies or procedures available more than a year ago? &, 986 & 1,014 \\
\cline { 2 - 4 } & TEA: How many -potential- customers consider the product new/unfamiliar? &, 986 & 1,014 \\
\hline
\end{tabular}

Source. Prepared by the author based on GEM, 2016 - output SPSS V23.

\subsection{Model adjustment}

For block 1 of the model, the efficiency score of the ROA statistics indicates that there is a significant improvement in the prediction of the probability of occurrence of the categories of the dependent variable (Chi-square 90, 573, df 3, p <.001).

Table 5. Omnibus tests of model coefficients

\begin{tabular}{|c|c|c|c|c|}
\hline \multicolumn{2}{|l|}{} & Chi-square & df & Sig. \\
\hline Step 1 & Step & 90,573 & 3 &, 000 \\
\hline & Block & 90,573 & 3 &, 000 \\
\hline & Model & 90,573 & 3 &, 000 \\
\hline
\end{tabular}

Source. Prepared by the author based on the database GEM, 2016 - output SPSS V23.

Table 6. Model summary

\begin{tabular}{|c|c|c|c|}
\hline Step & $\begin{array}{c}-2 \text { Log } \\
\text { Likelihood }\end{array}$ & $\begin{array}{c}\text { Cox \& Snell } \\
\text { R-square }\end{array}$ & $\begin{array}{c}\text { Nagelkerke } \\
\text { R-square }\end{array}$ \\
\hline 1 & $2665,367 \mathrm{a}$ &, 27 &, 48 \\
\hline
\end{tabular}

Source. Prepared by the author based on the database GEM, 2016 - output SPSS V23.

The $\mathrm{N}$-square value of Nagelkerke indicates that the proposed model explains $48 \%$ of the variance of the dependent variable - -48 -

Table 7. Classification table

\begin{tabular}{|c|c|c|c|c|c|}
\hline & & & & edicted & \\
\hline & Observed & & $\begin{array}{l}\text { TEA: strong } \\
\text { more than } 2 \\
\text { country- }\end{array}$ & $\begin{array}{l}\text { ientation - } \\
\text { om outside }\end{array}$ & Correct Percentage \\
\hline & & & No & Yes & \\
\hline & TEA: strong international & No & 2759 & 0 & 100,0 \\
\hline Step 1 & $\begin{array}{l}\text { orientation (more than } 25 \% \text { of } \\
\text { revenue from outside country) }\end{array}$ & Yes & 490 & 0 & 0 \\
\hline & Global Percentage & & & & 84,9 \\
\hline
\end{tabular}

Source. Prepared by the author based on the database GEM, 2016 - output SPSS V23. 
For the logistic regression analysis, the block indicates that there is an $84.9 \%$ probability of success in the result of the dependent variable when you know the value of the independent variables that are being used. In other words, when we make predictions with this model, there is an $84,9 \%$ chance of guessing right.

\subsection{Results of the model}

Table 8. Variables in the equation

\begin{tabular}{|c|c|c|c|c|c|c|c|}
\hline \multicolumn{2}{|c|}{} & B & Standard Error & Wald & df & Sig. & Exp(B) \\
\hline \multirow{4}{*}{ Step $1^{a}$} & TEATECH &, 898 &, 126 & 51,000 & 1 &, 000 & 2,454 \\
\cline { 2 - 8 } & TEACUST &, 638 &, 113 & 31,575 & 1 &, 000 & 1,892 \\
\cline { 2 - 8 } & FRFAILOP &,- 142 &, 128 & 1,230 & 1 &, 267 &, 868 \\
\cline { 2 - 8 } & Opport & -236 &, 122 & 3.434 & 1 &, 154 &, 567 \\
\cline { 2 - 8 } & Constante & $-2,280$ &, 101 & 505,604 & 1 &, 000 &, 102 \\
\hline
\end{tabular}

Source. Prepared by the author based on the database GEM, 2016 - output SPSS V23.

In order to interpret the results, it should be noted that the following reference or base levels were established: for process innovation — teactech$=$ technologies of more than one year; for product innovation - teacust $-=$ none; for opportunity $=$ no; and for risk aversion $=$ yes.

The Wald score for the model tested indicates that the variables innovation of processes and innovation of products contribute significantly to the prediction of the dependent variable, and the positive sign indicates that the greater the orientation to innovation, the greater the probability of being a BG firm. The variables of proactivity and risk aversion turned out to be non-significant, so hypotheses one and three can be validated.

Companies where CEOs are oriented towards innovation have better results. Thus, those that incorporate process innovation have an 89,2 \% chance of being a Global Born. Those that use state-of-the-art technologies in their production processes increase the probability of being BG by 1.454 times. This validates the position of authors like Miller and Friesen (1983), and Knight and Cavusgil (2004), and ratifies the importance of innovation as one of the main strategies when initiating an internationalization process.

\section{Conclusions and discussion}

$T^{3}$ he purpose to this document was review the relationship between export intensity, defined as the proportion of profits generated by a company's sales abroad within the total sales and the psychological variables of the CEOs, such as proactivity, orientation to innovation and risk tolerance in a special type of firms such as Born Global, which are characterized by their rapid incorporation into the international market.
The results indicate that the orientation to innovation as a psychological characteristic of a $\mathrm{CEO}$ is key to achieving internationally competitive products. This validates the position of authors like Miller and Friesen (1983) and Knight and Cavusgil (2004), and indicates that the export promotion policies have fallen short, because in Latin America, they have basically focused on providing a small part of all the information that is needed. 
It supposes entrepreneurs need thorough market studies, and in general, training in overcoming other market failures (Volpe, 2010). But as this document demonstrates, the relationship between innovation and internationalization is clear, so these policies should include explicit strategies for the firms that want to internationalize to decidedly incorporate innovation strategies and/or improve the existing ones. In other words, strategies to promote internalization must incorporate clear innovation actions within companies, and not work separately as is the current situation.

The limitations in the elaboration of this document are mainly related to the methodology. First of all and since it is a cross-sectional analysis, it leaves out the changes that take place over time. Secondly, the dependent variable does not capture all the elements that would express a successful internationalization, such as the number of countries to which it is exported.

According to the above and for future research, we suggest to perform longitudinal studies that could capture changes in personality. Another suggestion would be to include other demographic variables such as age or gender, which undoubtedly influence the personality of the individual and end up influencing the results of the company.

\section{References}

Acedo, J.; Jones, M. (2007). Speed of internationalization and entrepreneurial cognition: insights and a comparison between International New Ventures, exporters and domestic firms. Journal of World Business, 42(3), 236-252. DOI: https://doi. org/10.1016/j.jwb.2007.04.012

Ahmed, Z.; Julian, C.; Baalbaki, I.; Hadidian, T. (2004): Export barriers and firm internationalization: A study of Lebanese entrepreneurs. Journal of Management \& World Business Research, 1(1), 11-22.

Alderete, A. (2006). Fundamentos del análisis de la regresión logística en la investigación psicológica. Revista Evaluar, 6(1), 52-67.
Arenius, P.; Minniti, M. (2005). Perceptual variables and nascent entrepreneurship. Small Business Economics, 24(3), 233-247. DOI: https://doi.org/10.1007/s11187-005-1984-x

Bell, J. (1995). The internationalization of small computer software firms: a further challenge to "stage" theories. European Journal of Marketing, 29(8), 60-75. DOI: https:// doi.org/10.1108/03090569510097556

Bonaccorsi, A. (1992). On the relationship between firm size and export intensity. Journal of International Business Studies, 23(4), 605-635. DOI: https://doi.org/10.1057/palgrave. jibs. 8490280

Caliendo, M.; Fossen, F.; Kritikos, A. (2009). Risk attitudes and nascent entrepreneur: new evidence from an experimentally validated survey. Small Business Economics, 32(2), 153-167. DOI: https://doi.org/10.1007/s11187-007-9078-6

Capar, N.; Kotabe, M. (2003). The relationship between international diversification and performance in service firms. Journal of International Business Studies, 34(4), 345-355. DOI: https://doi.org/10.1057/palgrave.jibs.8400036

Cavusgil, S. (1984). Organizational characteristics associated with export activity. Journal of Management Studies, 21(1), 3-22. DOI: https://doi.org/10.1111/j.1467-6486.1984. tb00222.x

Corviello, N.; Munro, H. (1995). Growing the entrepreneurial firm: networking for international market development. European Journal of Marketing, 29(7), 49-61. DOI: https:// doi.org/10.1108/03090569510095008

Dimitratos, P.; Johnson, J.; Slow, J.; Young, S. (2003). Micromultinationals: New types of firms for the global competitive landscape. European Management Journal, 21(2), 164-174. DOI: https://doi.org/10.1016/S02632373(03)00011-2

Dimitratos, P.; Lioukas, S.; Carter, S. (2004). The relationship between Entrepreneurship and International performance: the importance of domestic environment. International Business Review, 13(1), 19-41. DOI: https://doi.org/10.1016/j. ibusrev.2003.08.001

Fernandez, Z.; Nieto, M. J. (2006). The impact of ownership on the international involvement of SMEs. Journal of International Business Studies, 37(3), 340-351. DOI: https:// doi.org/10.1057/palgrave.jibs.8400196

Geringer, M. J.; Tallman, S.; Olsen, D. M. (2000). Product and international diversification among Japanese multinational firms. Strategic Management Journal, 21(1): 51-80. DOI: https://doi.org/10.1002/(SICI)10970266(200001)21:1<51::AID-SMJ77>3.0.CO;2-K

Global Entrepreneurship Monitor - GEM (2015): Reporte Regional de México. México D.F.: Tecnológico de Monterrey

Global Entrepreneurship Monitor - GEM (2016): Reporte Regional de México. México D.F.: Tecnológico de Monterrey 
Hambrick, D.; Mason, P. (1984). Upper Echelons: the organization as a reflection of its top managers. Academy of Management Review, 9(2), 195-206. DOI: https://doi. org/10.5465/amr.1984.4277628

Jantunen, A.; Nummela, N.; Puumalinen, K.; Saarenketo, S. (2008). Strategic orientations of born globals - Do they really matter? Journal of World Business, 43(2), 158-170. DOI: https://doi.org/10.1016/j.jwb.2007.11.015

Johanson, J.; Vahlene, J. (1977). The internationalization of the firm: a model of Knowledge development and increasing foreign market commitments. Journal of International Business Studies, 8(1), 23-32. DOI: https://doi.org/10.1057/palgrave. jibs. 8490676

Johanson, J.; Vahlene, J. (1990). The mechanism of internationalization. International Marketing Review, 7(4), 1124. DOI: https://doi.org/10.1108/02651339010137414

Jones, M. V.; Coviello, N.; Tang, Y. K. (2011), International Entrepreneurship research (1989-2009): a domain ontology and thematic analysis. Journal of Business Venturing, 26(6), 632659. DOI: https://doi.org/10.1016/j.jbusvent.2011.04.001

Knight G.; Cavusgil, S. (1996). The born global firm: A challenge to traditional internationalization theory. En S.T. Cavusgil \& Madsen S.T. (ed). Export internationalizing research-enrichment and challenges (Advances in international Marketing, 8). (1126). New York: JAI Press.

Knight, G. (2000). Entrepreneurship and marketing strategy: The SME under globalization. Journal of International Marketing, 8(2),12-32. DOI: https://doi. org/10.1509\%2Fjimk.8.2.12.19620

Kuivalainen, O.; Sundqvist, S.; Servais, P. (2007). Firms' degree of born-globalness, international entrepreneurial orientation and export performance. Journal of World Business, 42 (3), 253267. DOI: https://doi.org/10.1016/j.jwb.2007.04.010

Kundu, S. K.; Katz, J. A. (2003). Born-international SMEs: Bi-level impacts of resources and intentions. Small Business Economics, 20(1), 25-47. DOI: https://doi. org/10.1023/A:1020292320170

Leiblein, M.; Reuer, J. (2004): Building a foreign sales base: the roles of capabilities and alliances for entrepreneurial firms. Journal of Business Venturing, 19 (2), 285-307. DOI: https:// doi.org/10.1016/S0883-9026(03)00031-4

Leonidou, L.; Katsikeas, S.; Piercy, N. (1998). Identifying managerial influences on exporting: past research and future directions. Journal of International Marketing, 6(2), 74-102. DOI: https://doi.org/10.1177\%2F1069031X9800600205

Liesch, P.; Welch, L.; Buckely, P. (2001): Risk and uncertainty in internationalization and international entrepreneurship studies. Management international studies, 51(6), 851-873. DOI: https://doi.org/10.1007/s11575-011-0107-y
Madsen, T.; Servais, P. (1997). The internationalization of Born Globals: An evolutionary process? International Business Review, 6(6), 561-583. DOI: https://doi.org/10.1016/ S0969-5931(97)00032-2

Matlay, H.; Andersson, S.; Evangelista, F. (2006). The entrepreneur in the Born Global firm in Australia and Sweden. Journal of Small Business and Enterprise Development, 13(4), 642-659. DOI: https://doi.org/10.1108/14626000610705796

McAuley, A. (1999). Entrepreneurial instant exporters in the Scottish arts and crafts sector. Journal of International marketing, 7(4), 67-82. DOI: https://doi. org/10.1177\%2F1069031X9900700405

Miesenbock, K. (1988). Small Business and exporting: a literature Review. International Small Business Journal, 6(2), 42-61. DOI: https://doi.org/10.1177\%2F026624268800600204

Milanov, H.; Fernhaber, S. A. (2009). The impact of early imprinting on the evolution of new venture networks. Journal of Business Venturing, 24(1), 46-61. DOI: https://doi. org/10.1016/j.jbusvent.2007.11.001

Miller, D. (1983). The correlates of Entrepreneurship in three types of firms. Management Science, 29(7), 770-791. DOI: https://doi.org/10.1287/mnsc.29.7.770

Miller, D.; Friesen, P. (1983). Strategy-making and environment: the third link. Strategic Management Journal, 4(3), 221-235. DOI: https://doi.org/10.1002/smj.4250040304

Moen, O. (2002). The Born Globals: A new generation of small European exporters. International Marketing Review, 19(2), 156175. DOI: https://doi.org/10.1108/02651330210425015

Moini, A. (1997). Barriers Inhibiting Export Performance of Small and Medium-sized Manufacturing Firms. Journal of Global Market, 10(4), 67-93. DOI: https://doi.org/10.1300/ J042v10n04_05

O'Cass, A.; Julian, C. (2003). Examining firm and environmental influences on export marketing mix strategy and export performance for Australian exporters. European Journal of Marketing, 37(3/4), 366-384. DOI: https://doi. org/10.1108/03090560310459005

Organization for Cooperation and Development - OECD. (2005). Oslo Manual: Guidelines for Collecting and Interpreting Innovation Data, Third Edition. OECD/European Communities

Oviatt, B. M.; McDougall, P. P. (1994). Toward a theory of international new ventures. Journal of International Business Studies, 25(1), 45-64. DOI: https://doi.org/10.1057/ palgrave.jibs. 8490193

Preece, S.; Miles, G.; Baetz,M. (1998).Explaining the international intensity and global diversity of Early-stage technology-based firms. Journal of Business Venturing, 14, 259-281. DOI: https:// doi.org/10.1016/S0883-9026(97)00105-5 
Reid, S. (1983). Managerial and firm influences on export behavior. Journal of the Academy of Marketing Science, 11(3), 323-332. DOI: https://doi. org/10.1177\%2F009207038301100312

Rialp, A; Rialp, J.; Knight, G. A. (2005). The phenomenon of early internationalizing firms: What do we know after a decade (1993-2003) of scientific inquiry? International Business Review, 14(2), 147-166. DOI: https://doi.org/10.1016/j. ibusrev.2004.04.006

Robertson, C.; Chetty, S. (2000). A contingency based approach to understanding export performance. International Business Review, 9, 211-235. DOI: https://doi.org/10.1016/S09695931(99)00037-2

Roth, K. (1995). Managing international interdependence: CEO characteristics in a resource-based framework. Academy of Management Journal, 38(1): 200-231. DOI: https://doi. org/10.5465/256733

Ruzzier, M.; Antoncic, B.; Hisrich, R.; Konecnic, M. (2007): Human capital and SME internationalization: A structural equation modeling study. Canadian Journal of Administrative Sciences, 24 (1), 15-29. DOI: https://doi.org/10.1002/cjas.3

Sanders, V.; Carpenter, M. (1998). Internationalization and firm governance: the roles of CEO compensation, top team composition, and board structure. Academy of Management Journal, 41(2), 158-178. DOI: https://doi. org/10.2307/257100

Tallman, S.; Li, J.T. (2006). Effects of international diversity and product diversity on the performance of multinational firms. Academy of Management Journal, 39(1), 179-196. DOI: https://doi.org/10.2307/256635

Tihanyi, L.; Thomas, W. (2005). Information processing demands and the multinational enterprise: A comparison of foreign and domestic earnings estimates. Journal of Business Research, 58(3), 285-292. DOI: https://doi.org/10.1016/ S0148-2963(03)00133-4

Trabold, H. (2002). Export intermediation: An empirical test of Peng and Ilinitch. Journal of International Business Studies, 33(2), 327-344. DOI: https://doi.org/10.1057/palgrave. jibs.8491019

Venkatraman, N. (1989). Strategic orientation of business enterprises: the construct, dimensionality, and measurement. Management Science, 35(8), 942-962. DOI: https://doi. org/10.1287/mnsc.35.8.942

Volpe, C. (2010). Odisea en los mercados internacionales. Una evaluación de la efectividad de la promoción de exportaciones en América Latina y el Caribe. Washington D. C.: Banco Interamericano de Desarrollo.

Wakelin, K. (1998). Innovation and export behavior at the firm level. Research Policy, 26 (7-8), 829-841. DOI: https://doi. org/10.1016/S0048-7333(97)00051-6
Zhara S. A.; Garvis, D. (2000). International Corporate Entrepreneurship and firm performance: the moderating effect of international environmental hostility. Journal of Business venturing, 15:469-492. DOI: https://doi. org/10.1016/S0883-9026(99)00036-1

Zhou, L.; Barnes, B.; Lu, Y. (2010). Entrepreneurial proclivity, capability upgrading and performance advantage of newness among international new ventures. Journal of international Business Studies, 41(5), 882-905. DOI: https://doi. org/10.1057/jibs.2009.87 
is 